\title{
The Role of Government and Industry toward Vocational Schools and their Impact on Graduates' Quality of Culinary and Hospitality Students in Makassar
}

\author{
Nahriana \\ Engineering Faculty \\ Makassar State University \\ Makassar, Indonesia \\ nahrianaftunm@yahoo.com
}

\author{
Andi Muadz Palerangi \\ Engineering Faculty \\ Makassar State University \\ Makassar, Indonesia
}

\begin{abstract}
This study aims to investigate the contribution or the role of government (X1), industry (X2) toward vocational school $(Y)$ and their impact to graduates' quality $(Z)$ both direct and indirect contribution. It is a quantitative study. The population of this study was 335 Culinary and Hospitality students in Makassar. This study used proportional random sampling technique in selecting the sample of research and the result was 150 students. In collecting the data, questionnaire and documentation were used. This study employed descriptive analysis and path analysis. The results of the research indicated that all path coefficients were significant so that the alternative hypothesis (ha) was accepted, with the following description: (1) there was a significant contribution of government role to the vocational school of $52.5 \%$; (2) there was a significant contribution of industry to vocational school of $33.8 \%$; (3) there was a significant contribution of the government's role to the quality of graduates of $29.8 \%$; (4) there was a significant contribution of the industry to the quality of graduates in the field of expertise of $22.8 \%$ and; (5) there was a significant contribution of vocational school to the quality of graduates of $38.8 \%$.
\end{abstract}

Keywords—government, industry, vocational school, graduates quality

\section{INTRODUCTION}

The rapid development of industry had an impact on the paradigm shift in meeting the labor needs. Its is marked by the introduction of the industrial revolution era 4.0. Vocational education is organized as a medium in facilitating and preparing skilled labor. Regarding to this, vocational school is always trying to anticipate all the needs in preparing skilled, qualified and professional manpower as well as having competitive level and productive ability globally.

Sonhadji presented three main characteristics of vocational education that need to be considered in the implementation, such as (1) the emphasis on the psychomotor domain that is compatible with technological development and work orientation; (2) vocational high schools as a vocational education and training institution should be developed in the direction of education capable of preparing students to become professional workers and; (3) able to develop a strong personality and high thinking ability [1]. To achieve this, vocational schools, management must be oriented on the quality of graduates. However, the conditions that occur show that the psychomotor domain is still not optimally emphasized in the implementation of vocational education. Vocational high schools as a vocational institution need to conduct competence test to their graduates in order to get a certification as mastering the particular competence according to the standard competence.

Vocational schools could play a key role in economic development as long as its alignment with the industry is sought continuously, both in terms of quantity, quality, location, and time [2]. The relevance is still a central issue of the quality of vocational education in developing countries including Indonesia. The relevance of vocational education is closely related to the matching among programs held in schools, the need for work competence in work and industry, the needs of self-development of vocational education users (parents of learners and participants educated), and the needs of regional economic development, including social, cultural and political needs [3]. In the same vein, the results of research conducted by Boediono and McMahon suggested that investment in education contributes greatly to economic development in Indonesia [4].

Finch \& Crunkilton stated that the relevance of school curriculum to industry can be achieved with the involvement of the stakeholders of vocational education [5]. Therefore, to assess whether such school is in good quality, that is where the school has the power that is suitable with the work world. Rosyada described that stakeholder is one of the categories of school society which is one of important elements, if one of them does not exist then the process of schooling becomes disrupted [6]. Therefore, the synergy between schools and stakeholders must be well established. In line with that opinion, Kompri stated that stakeholders are related components having equal rights and obligations in planning, implementing and monitoring the education program [7].

In producing qualified education and relevant to stakeholder needs, vocational schools management should pay attention to world of work and industry needs, community needs, central government needs, and local government. Xinwu explained that when the synergy of stakeholders with the world of education is not maximum, it will affect the development and sustainability of the quality of educational graduates [8].

The quality of vocational education can be viewed from three aspects: (1) product quality; (2) process quality; and (3) service quality. Good synergy by all parties will realize the achievement of these three qualities. The synergy of vocational 
education is not only effective in producing the quality of education, but more than that, the impact will have a positive effect on the national economic interests in the fulfillment of the productive workforce and become a strategy to face the rapidly growing international economic competition_[9]. The outcomes of vocational schools are expected to act locally and develop globally as a strong local person maintaining traditional and international values [10].

Culinary services is a service industry engaged in the provision of food and beverages. It encourages the availability of skilled manpower in the field of culinary and hospitality accommodation, one of which can be obtained from vocational schools graduates. Even though in reality, the field of work is not only taken by the vocational graduates, but the relevance of the vocational schools graduates competence is very suitable for the field of work, thus they are more ready to work than other secondary education graduates. In addition, as a tourist destination both domestic and foreign tourists, Makassar every year has increased the number of visits. For the domestic tourists who visited Makassar in 2011 was 4.471 .632 has increased in 2015 to 7128.826 , while foreign tourists who visited Makassar in 2011 as many as 51.749 increased in 2015 rose to 191.773 .

Based on the observation of vocational schools in culinary and hospitality in Makassar related to the synergy of stakeholders, it is found that school stakeholder partnership is still low in encouraging graduates. It is resulted in various problems such as (1) the diversity of geographycal, (2) the diversity of vocational schools readiness, (3) the diversity of vocational schools programs that have not been balanced with the surrounding industry diversity, (4) the supervisor teacher not yet optimally functioned in industry, (5) the difficulties in establishing cooperation with partner institutions that are classified as medium and large, (6) the low management of training of students by industry, especially small industry, (7) the lack of time at school provided by the school to coordinate, (8) the graduates not ready (10) the low learning motivation, (11) the inadequate facilities and infrastructure, (12) the low discipline and awareness of learners to safety, (13) the unbalanced between the number of vocational schools and the number of business and industry, (14) the lack of teachers' ability to deliver hardskill and interesting softskill, (16) the lack of management of apprenticeship by schools, (17) the lack or unavailability of stock exchange work and career guidance in schools / training institutions, (18) the absence of rules that bind the industry to cooperate with vocational schools.

\section{METHOD}

Referring to the description of the proposed problem and objectives, the design of this study was a quantitative approach with a survey method, in which researchers described quantitatively, the trends, behaviors or opinions of a population by examining the population sample [11]. This design aims to see the contribution of independent variables to dependent variables through causal relationships using path analysis with decomposition model. The variables in this study consisted of exogenous variables namely; Government $\left(\mathrm{X}_{1}\right)$ and Industrial
World $\left(\mathrm{X}_{2}\right)$, intervening variable namely Vocational Education Organizer (Y) and endogen variable namely Graduation Quality (Z).

Population in this research was all public and private vocational high schools which have study program expertise of Culinary and Hospitality in Makassar with total of 335 students. Sampling technique used in this research was proportional random sampling. To obtain the total sample, this study used Taro Yamane formula with the level of precision specified (error rate, $\alpha=5 \%$ ) obtained the sample number of 150 students [12].

Data analysis conducted in the research consist of analysis (1) inferential descriptive statistic, (2) the prerequisite analysis test, and (3) path analysis. Researchers used SPSS 20 program assistance with a $5 \%$ significance level guideline to see how much the donation of exogenous has been given to the endogenous variable.

\section{RESULT}

The result of the research is explained in a description of each variable, prerequisite test, and hypothesis test either partially or individually. The following is a description of the research results.

\section{A. Data Description}

\section{1) Government Roles}

Description of government roles variable includes 5 subvariables. The total number of questions used was 38 items. The average score of 3.05 has given the idea that government roles in Makassar was well implemented. Thus, the distribution of research data on industrial role variables can be said to be normally distributed.

\section{2) Industrial Roles}

Description of the industry role variables includes 4 subvariables. The total number of questions used was 28 items. Kolmogorov-Smirnov test results with p value of 0.368 ( $p>$ $0.05)$. Thus, the distribution of research data of industrial role variables was normally distributed.

\section{3) Vocational Schools Roles}

Description of the role of vocational schools includes 5 sub-variables. The total number of questions used were 63 items. Kolmogorov-Smirnov test results with $\mathrm{p}$ value of 0.192 ( $p>0.05$ ). Thus, the distribution of the data on the role of vocational schools variables is normally distributed.

\section{4) Graduates Quality}

Description of Graduates Quality includes 3 sub-variables. The distribution of research data on graduate quality roles variable was not normally distributed. Distribution of indicators from the quality of graduates indicates that the readiness is below average, while the indicators of competence and skills are above average.

\section{B. Data Analysis}

\section{1) Normality Test}

The normality test norm is if the probability value (asym.sig) > 0,05 then the data is normally distributed. 
Conversely, if the probability value (asym.sig) is less than 0.05 then the data is not normally distributed. The result shows that all data were normally distributes since the probability value of each variable is bigger than 0,05 .

\section{2) Linearity Test}

Linearity test aims to determine whether between exogenous and endogenous variables have a linear relationship. Based on the result of linearity test, it can be concluded that the relationship between variables $\mathrm{X}_{1}, \mathrm{X}_{2}$ to $\mathrm{Y}$ or $\mathrm{Z}$ has a linear pattern.

\section{3) Multicollinearity Test}

Multicollinearity test aims to determine whether there is a correlation between independent variables. Based on the multicollinearity test, it is concluded that the relationship between variables $\mathrm{X}_{1}, \mathrm{X}_{2}$ to $\mathrm{Y}$ or $\mathrm{Z}$ has a VIF value no more than 10 , which means no multicollinearity.

\section{Hypothesis Testing}

\section{First Sub-Structure Analysis}

\section{1) First Simultaneous Sub-Structure Test Analysis}

Testing simultaneously in the first sub-structure aims to find out to what extent the contribution of exogenous variables: the role of government $\left(\mathrm{X}_{1}\right)$ and industry $\left(\mathrm{X}_{2}\right)$ toward the intervening variables: vocational education administration vocational (Y). The simultaneous test results of the first substructure with the help of SPSS 20 for windows can be seen in Table I and Table II as follows.

TABLE I. THE RESULTS OF THE FIRST SUB-STRUCTURAL SIMULTANEOUS SUMMARY MODEL TESTING

\begin{tabular}{|l|c|l|l|l|}
\hline \multicolumn{5}{|c|}{ Model Summary } \\
\hline Model & \multicolumn{1}{|c|}{$\boldsymbol{R}$} & $\boldsymbol{R}$ Square & Adjusted R Square & Std. Error of the Estimate \\
\hline 1 & $.523^{\mathrm{a}}$ & .273 & .258 & 4.626 \\
\hline
\end{tabular}

Based on Table $\mathrm{V}$ above, it is known that the coefficient of determination R Square (R2) or simultaneous contribution of 0.273 , which means the contribution of variables $\mathrm{X}_{1}$ and $\mathrm{X}_{2}$ simultaneously to $\mathrm{Y}$. So it can be concluded that the contribution of variables $\mathrm{X}_{1}$ and $\mathrm{X}_{2}$ to variable $\mathrm{Y}$ simultaneously was $27.3 \%$. Meanwhile, the contribution of variables or other factors was $\rho y \varepsilon_{1}=1-0.273=0.727=$ 72.7.\%. Furthermore, to calculate the significant level of constant can be seen in Table Anova as follows.

TABLE II. ANOVA TESTING RESULTS SIMULTANEOUSLY ON THE FIRST SUB-STRUCTURAL

\begin{tabular}{|c|c|c|c|c|c|c|}
\hline \multicolumn{7}{|c|}{ ANOVAa } \\
\hline & Model & $\begin{array}{c}\text { Sum of } \\
\text { Squares }\end{array}$ & $D f$ & Mean Square & $\boldsymbol{F}$ & Sig. \\
\hline \multirow{3}{*}{1} & Regression & 342.222 & 2 & 325.815 & 12.725 & $.000 \mathrm{~b}$ \\
\hline & Residual & 24271.351 & 146 & 18.572 & & \\
\hline & Total & 366.4933 & 149 & & & \\
\hline \multicolumn{7}{|c|}{ a. Dependent Variable: GQ } \\
\hline \multicolumn{7}{|c|}{ b. Predictors: (Constant), GR, IR } \\
\hline
\end{tabular}

Based on Table XIV ANOVAa shows simultaneous test results on the first sub-structure. Since the value of sig $<0,05$ $(0,000<0,05)$, then Ho is rejected and Ha accepted which means there are significant contribution of variable $\mathrm{X}_{1}$ and $\mathrm{X}_{2}$ to Variable Y, so it can be continued with test individually.

\section{2) The Result of First Individual Sub-Structure Test}

Individual testing on the first sub-structure aims to know the significance of path analysis with a probability value ratio of 0.05 . The first individual sub-structural test results with the help of SPSS 20 for windows can be seen in Table VII. and Table VIII as follows.

TABLE III. SUMMARY OF FIRST SUB-STRUCTURE CORRELATION RESULTS

\begin{tabular}{|c|c|c|c|c|}
\hline No & Variables & Correlation (r) & Sig. & KP(r2 x 100) \\
\hline 1 & $\mathrm{X}_{1}$ towards $\mathrm{Y}$ & 0,428 & 0,000 & $\begin{array}{ll}0,183 & \text { or } \\
18,4 \% & \end{array}$ \\
\hline 2 & $\mathrm{X}_{2}$ towards $\mathrm{Y}$ & 0,281 & 0,000 & 0,078 or $7,8 \%$ \\
\hline 3 & $\mathrm{X}_{1}$ towards $\mathrm{X}_{2}$ & 0,653 & 0,000 & $\begin{array}{ll}0,426 & \text { or } \\
42,6 \% & \end{array}$ \\
\hline
\end{tabular}

TABLE IV. COEFFICIENTS TEST RESULTS INDIVIDUALLY THE FIRST SUBSTRUCTURE

\begin{tabular}{|c|c|c|c|c|c|c|}
\hline \multicolumn{7}{|c|}{ Coefficients $^{\mathrm{a}}$} \\
\hline & \multirow[t]{2}{*}{ Model } & \multicolumn{2}{|c|}{$\begin{array}{l}\text { Unstandardized } \\
\text { Coefficients }\end{array}$} & \multirow{2}{*}{\begin{tabular}{|c|}
$\begin{array}{c}\text { Standardized } \\
\text { Coefficients }\end{array}$ \\
Beta \\
\end{tabular}} & \multirow[t]{2}{*}{$\mathbf{T}$} & \multirow[t]{2}{*}{ Sig. } \\
\hline & & $B$ & Std. Error & & & \\
\hline \multirow{3}{*}{1} & Constant & 6.478 & 3.838 & & 1.688 & .094 \\
\hline & $\mathrm{X}_{1}$ & .811 & .056 & .725 & 8.538 & .000 \\
\hline & $\mathrm{X}_{2}$ & .149 & .052 & .582 & 2.764 & .005 \\
\hline
\end{tabular}

The test results individually between variables $\mathrm{X}_{1}$ to $\mathrm{Y}$, obtained $t_{\text {value }}$ of 8,538 with sig 0,000 and that $\mathrm{H}_{0}$ is rejected and $\mathrm{Ha}$ accepted. It can be concluded that there was significant contribution between government role $\left(\mathrm{X}_{1}\right)$ to vocational education provider (Y). The amount of contribution is $33.8 \%$.

\section{Second Sub-Structure Analysis}

3) Second Simultaneous Sub-Structure Test Analysis

The simultaneous test on second sub-structure aims to know the contribution of exogenous variables namely the role of government $\left(X_{1}\right)$, the role of industrial world $\left(X_{2}\right)$ and intervening variable of vocational education provider of SMK $(\mathrm{Y})$ to the endogenous variable of graduates quality $(\mathrm{Z})$. The simultaneous test results of the second sub-structure can be seen in Table IX and Table $\mathrm{X}$ as follows.

TABLE V. COEFFICIENTS TEST RESULTS INDIVIDUALLY THE FIRST SUBSTRUCTURE

\begin{tabular}{|l|c|l|l|l|}
\hline \multicolumn{5}{|c|}{ Model Summary } \\
\hline Model & $\boldsymbol{R}$ & R Square & Adjusted $\boldsymbol{R}$ Square & Std. Error of the Estimate \\
\hline 1 & $.624^{\mathrm{a}}$ & .475 & .318 & 6.527 \\
\hline
\end{tabular}

Based on Table IX above, it is known that the coefficient of determination R Square (R2) or simultaneous contribution of 0.475 , which means the contribution of variables $\mathrm{X}_{1}, \mathrm{X}_{2}$ and $\mathrm{Y}$ 
simultaneously to Z . So it can be concluded that the variable contribution of $\mathrm{X} 1, \mathrm{X} 2$ and $\mathrm{Y}$ to variable $\mathrm{Z}$ simultaneously is $47.5 \%$. Meanwhile, the amount of contribution of variables or other factors is $\rho y \varepsilon 1=1-0.475=0.525=52.5 . \%$. Furthermore, to calculate the significant level of constants can be seen in Table Anova as follows.

TABLE VI. ANOVA TESTING RESULTS SIMULTANEOUSLY ON THE SECOND SUB-STRUCTURAL

\begin{tabular}{|l|l|l|l|l|l|c|}
\hline \multicolumn{2}{|c|}{ ANOVAa } \\
\hline \multicolumn{2}{|c|}{ Model } & $\begin{array}{c}\text { Sum of } \\
\text { Squares }\end{array}$ & Df & $\begin{array}{c}\text { Mean } \\
\text { Square }\end{array}$ & F & Sig. \\
\hline \multirow{4}{*}{1} & Regression & 1174.546 & 3 & 391.515 & 18.292 & $.000 \mathrm{~b}$ \\
\cline { 2 - 8 } & Residual & 3124.954 & 147 & 21.404 & & \\
\cline { 2 - 7 } & Total & 4299.500 & 149 & & & \\
\hline \multicolumn{2}{|l|}{ a. Dependent Variable: GQ } \\
\hline \multicolumn{2}{|l}{ b. Predictors: (Constant), VHSR, IR, GR } \\
\hline
\end{tabular}

Based on Table X ANOVAa shows simultaneous test results in second sub-category, where the value of $F$ is 18.292 , with a probability value ( $\mathrm{sig}$ ) of 0.000 . Because the value of sig $<0,05(0,000<0,05)$, then Ho is rejected and Ha accepted which means there are significant contribution of variable $X_{1}$, $\mathrm{X}_{2}$ and $\mathrm{Y}$ to variable $\mathrm{Z}$, so it can be continued with test individually.

\section{4) Individual Test of Second Sub-Structure Analysis}

Individual test results in the second second sub-structure with the help of SPSS 20 can be seen in Table XI and Table $\mathrm{XII}$ as follows.

TABLE VII. SUMMARY OF FIRST SUB-STRUCTURE CORRELATION RESULTS

\begin{tabular}{|l|l|l|l|l|}
\hline No & Variables & Correlation $(\mathbf{r})$ & Sig. & KP(r2 x 100) \\
\hline 1 & $\mathrm{X}_{1}$ towards $\mathrm{Y}$ & 0,428 & 0,000 & 0,183 or $18,4 \%$ \\
\hline 2 & $\mathrm{X}_{2}$ towards $\mathrm{H}$ & 0,281 & 0,000 & 0,078 or $7,8 \%$ \\
\hline 3 & $\mathrm{X}_{1}$ towards $Z$ & 0,385 & 0,000 & 0,148 or $14,8 \%$ \\
\hline 4 & $\mathrm{X}_{2}$ towards $Z$ & 0,572 & 0,000 & 0,327 or $32,7 \%$ \\
\hline 5 & $\mathrm{Y}_{\text {towards } Z}$ & 0,507 & 0,000 & 0,257 or $25,7 \%$ \\
\hline 6 & $\mathrm{X}_{1}$ towards $\mathrm{X}_{2}$ & 0,653 & 0,000 & 0,426 or $42,6 \%$ \\
\hline
\end{tabular}

TABLE VIII. COEFFICIENTS TEST RESULTS INDIVIDUALLY ON THE SECOND SUB-STRUCTURE

\begin{tabular}{|c|c|c|c|c|c|c|}
\hline \multicolumn{7}{|c|}{ Coefficients $^{\mathrm{a}}$} \\
\hline & \multirow[t]{2}{*}{ Model } & \multicolumn{2}{|c|}{$\begin{array}{c}\text { Unstandardized } \\
\text { Coefficients }\end{array}$} & \multirow{2}{*}{\begin{tabular}{|c|}
$\begin{array}{c}\text { Standardized } \\
\text { Coefficients }\end{array}$ \\
Beta
\end{tabular}} & \multirow[t]{2}{*}{$\mathbf{t}$} & \multirow[t]{2}{*}{ Sig. } \\
\hline & & $B$ & Std. Error & & & \\
\hline \multirow{4}{*}{1} & (Constant) & 7.514 & 5.762 & & 3.523 & .012 \\
\hline & $\mathrm{X}_{1}$ & .625 & .232 & .546 & 6.276 & .000 \\
\hline & $\mathrm{X}_{2}$ & .327 & .421 & .478 & 2.241 & .005 \\
\hline & $Z$ & .237 & .175 & .623 & 4.125 & .002 \\
\hline
\end{tabular}

Individually, the test results between variables $\mathrm{X}_{1}$ to $\mathrm{Z}$, obtained $t_{\text {value }}$ of 6,276 with sig 0,000 . It is known that the value of sig $<0,05$ or $(0,000<0,05)$, mean $\mathrm{H}_{0}$ is rejected and $\mathrm{Ha}$ accepted, so it can be concluded that there is significant contribution between government role $\left(\mathrm{X}_{1}\right)$ to the quality of graduate $(Z)$. To know the amount of contribution can be seen from value $(\text { standardized coefficients beta })^{2}$ X $100=(0,546)=$ $0,298 \times 100=29,8 \%$.

The individual test between variables $\mathrm{X}_{2}$ to $\mathrm{Z}$, obtained $\mathrm{t}_{\mathrm{value}}$ of 2.241 with sig 0,000 . It can be concluded that there was a significant contribution between the role of industrial world $\left(\mathrm{X}_{2}\right)$ to the quality of the graduate $(\mathrm{Z})$. To know the amount of contribution can be seen from value (standardized coefficients beta $)^{2}$ X $100=(0,478)=0,228 \times 100=22,8 \%$ and test result individually between variable $X_{1}$ to $Z$, obtained $t_{\text {value }}$ equal 4,125 with sig 0,000 . It is known that the value of sig $<0,05$ or $(0,002<0,05)$, mean $\mathrm{H}_{0}$ is rejected and $\mathrm{Ha}$ accepted. The amount of contribution can be seen from value (standardized coefficients beta $)^{2}$ X $100=(0,3881)=0,388 \times 100=38,8 \%$.

\section{DISCUSSION}

\section{A. The Role of Government towards the Vocational Schools}

Based on the results of the test analysis that has been done on the first hypothesis indicating that there was a significant contribution of the role of government to the vocational schools in the field of expertise of Culinary and Hospitality in Makassar. The findings of research based on direct path analysis showed that the contribution of government $\left(\mathrm{X}_{1}\right)$ to vocational schools (Y) was $52,5 \%$. Therefore, to optimize the role of government, vocational schools should be able to synergize as a partner here, the government becomes a cooperative with the vocational schools. This finding is in-line with a research conducted by Sihombing which states that the government's role is expected to organize and strengthen the implementation of education [13].

Based on the supportive literature, it is concluded that the findings of this study indicated that the government in determining the policy in vocational education should be able to understand the state of education of each region, so that later there is no elements of coercion by the government.

\section{B. The Role of Industry towards the Vocational Schools}

According to Charles Prosser cited by Wardiman, there are three out of sixteen principles of vocational education which is related to the role of industry: (a) training tasks are performed in the same manner, tool, and machine as defined in the workplace; (b) training a person in the habit of thinking, and working as necessary in the work itself; and (c) vocational education will be efficient if the learning environment is similar to the real one [14]. This efficiency is obtained because the industry does not need to organize the centers of training again. The result of the test showed that there was a significant contribution of industry to vocational school. The findings of research based on direct path analysis showed that the contribution of industry role $\left(\mathrm{X}_{2}\right)$ to vocational school $(\mathrm{Y})$ was $33,8 \%$. Therefore, to optimize the role of industry, vocational school must be managed with reference to the main objective, which was preparing graduates who are ready to enter the world of work and employed.

\section{The Role of Government on Graduate Quality}

Implementation of the SPMP consists of a series of processes/ phases cyclically. Implementation of the above 
stages is carried out collaboratively between the educational unit and other relevant parties in accordance with the applicable provisions that is the organizer of educational unit or program, district or city government, the provincial government, and the government.

The result of the test analysis showed that there was a significant contribution of the government's role to the quality of graduates. The high level of government's role in the quality of graduates can determine the quality of vocational education providers. The findings of the research based on direct path analysis showed that the contribution of government role $\left(\mathrm{X}_{1}\right)$ to the quality of the graduate $(Z)$ was $29.8 \%$. Therefore, to optimize the role of government in improving the quality of graduates must be in accordance with the providers of vocational education.

Related to this finding, in producing qualified graduates, there are four fundamental efforts that must be done in an educational institution: (1) creating a win-win situation and not a win lose situation among stakeholders, (2) the need to develop an intrinsic motivation for everyone involved in the process of achieving quality, (3) every leader should be oriented to long-term processes and outcomes, and (4) in mobilizing the ability of educational institutions to achieve the stipulated quality, cooperation should be developed among the elements of the process of achieving the quality results [15].

\section{The Role of Industry on Graduate Quality}

According to Mulyasa, school relations with the community is essentially a very instrumental in fostering and developing personal growth of learners in school [16]. Increasing the quality of vocational school graduates requires an alignment between vocational school with industry. In the alignment program in question is the alignment of the supply side and demand side.

The results of the test analysis that has been done on the fourth hypothesis showed that there was a significant contribution of the role of industry to the quality of graduates. The high and low role of the industry on the quality of graduates can determine the quality of vocational education providers. The findings of research based on direct path analysis showed that the contribution of government role (X2) to the quality of the graduate $(\mathrm{Z})$ was $22.8 \%$. Therefore, to optimize the role of industry in improving the quality of graduates should be in synergy with the vocational education providers, especially in the preparation of the curriculum.

As has been discussed earlier, the role of industry in the learning process has been limited to the implementation of Field Industrial Practice. The results of Utami's study concluded that the partnership between vocational schools and industries in the implementation of Field Industrial Practice program strongly supports the improvement of the quality vocational schools graduates of hospitality in accordance with the competence of skills chosen by the students to meet the needs of the workforce in the business world and industry [17].

\section{E. The Role of Vocational Schools to Graduate Quality}

The factors that determine the competitive advantage of vocational schools, must be considered and managed well and professionally. These factors are human resources and school policy settings as well as the school itself. The results of the test analysis that has been done on the fifth hypothesis shows that there is a significant contribution of the role of vocational schools to the quality of graduate. This means that the research findings indicated that the role of vocational schools measured by the quality of graduates has a positive and significant contribution to the high and low role of government with the industry. The low role of vocational schools on the quality of graduates can determine the quality in producing skilled and professional workforce. The findings of research based on direct path analysis showed that the contribution of vocational education providers $(\mathrm{Y})$ to the quality of graduates $(\mathrm{Z})$ is $38.8 \%$. Therefore, to optimize the role of vocational schools in improving the quality of graduates should be in synergy with the government and the industrial world. These findings are reinforced by the results of Baedowi explains that teachers are responsible for encouraging students' independence in learning, fosters positive attitudes and perceptions of learning so as to improve the achievement of students' learning outcomes [18].

Referring to the related literature, it is concluded that the findings of this study indicated that the role of vocational schools has a very important influence on the quality of graduates. In line with the result, Muzenda_conducting research in South Africa found that subject knowledge, teaching skills, teacher attendance, and teacher attitudes have a significant positive effect on the academic achievement of learners [19]. Research conducted by Akiri in Nigeria with a sample of 300 teachers as respondents shows that effective teachers produce better performing learners [20]. High teacher competence affects high achievement of learners in reading and counting. Similarly, the result of Indonesian research by Astuty shows that the competence of teachers has a significant impact on the academic achievement of learners [21].

\section{CONCLUSION}

Based on the result of this study, it can be concluded that (1) There was a significant contribution of the government's role to the vocational school in the field of expertise Culinary and Hospitality in Makassar with $52.5 \%$, (2) There was a significant contribution of industry to vocational school with $33.8 \%$, (3) There was a significant contribution of the government's role to the quality of Graduates with $29.8 \%$, (4) There was a significant contribution of the industry to the quality of graduates with $22.8 \%$, and (5) There was a significant contribution of vocational school to the quality of graduates with $38.8 \%$.

\section{REFERENCES}

[1] Sondhadji, A. 2013. Manusia, Teknologi dan Pendidikan Menuju Peradaban Baru. Malang: UM Press.

[2] Slamet. 2011. Peran Pendidikan Vokasi dalam Pembangunan Ekonomi. Jurnal Cakrawala Pendidikan, 30 (2): 190-202.

[3] Boutin, F., Chinien, C., Moratis, L., Baalen, P.V. 2009. Overview: Changing Economic Environment and Workplace Requirements: Implications for Re-Engineering TVET for Prosperity. In R. Maclean, D. 
Wilson, \& C. Chinien (Eds.), International Handbook of Education for the Changing World of Work, Bridging Academic and Vocational Learning. Germany: Springer.

[4] Boediono \& McMahon. 2001. Pembangunan Pendidikan untuk Mendukung Pertumbuhan Ekonomi. Jakarta: Badan Penelitian dan Pengembangan, Departemen Pendidikan dan Kebudayaan

[5] Finch \& Crunkilton. 1999. Curriculum development in Vocational and Technical Education. Boston: Allyn and Bacon.

[6] Rosyada, Dede. 2004. Paradigma Pendidikan Demokratis: Sebuah Model Pelibatan Masyarakat dalam Penyelenggaraan Pendidikan. Jakarta: Kencana.

[7] Kompri. 2014. Manajemen Sekolah: Teori dan Praktek. Bandung: Alfabeta.

[8] Xingwu, L. 2012. Mechanism of Synergy between Enterprise Group and Its Higher Vocational College and Its Realization:taking Zhejiang Province as an example. http://en.cnki.com.cn/Article_en/CJFDTOTALSHGJ201219011.htm. Accessed on 10 May 2018.

[9] Okoye, K. R. E., \& Okwelle, P. C. (2013). Complex Mix of Sociopolitical Synergy on Technical Vocational Education and Training (TVET) in Nigeria. Kuwait Chapter of the Arabian Journal of Business and Management Review, 3(3), 28.

[10] Cheng, Y.C. 2005. New Paradigm for Re-engineering Education, Globalization, Localization and Individualization. Netherland: Springer.

[11] Creswell, W.J. 2013. Research Design, Pendekatan Kualitatif, Kuantitatif, dan Mixed. Third Edition. Yogyakarta: Pustaka Pelajar.

[12] Riduwan, K. E. A., \& Achmad, E. 2007. Cara menggunakan dan memakai analisis jalur (path analysis). Penerbit: Alfabeta. Bandung.
[13] Sihombing, 2001. Konsep dan Pengembangan Pendidikan Berbasis Masyarakat dalam Fasli Jalal dan Dedi Supriadi (Eds.), Reformasi Pendidikan dalam Konteks Otonomi Daerah, Yogyakarta: Adicita Karya Nusa.

[14] Wardiman, 1998. Pengembangan Sumber Daya Manusia melalui Sekolah Menengah Kejuruan (SMK). Departemen Pendidikan dan Kebudayaan: Jakarta

[15] Slamet, M. 1999. Filosofi Mutu dan Penerapan Prinsip-Prinsip Manajemen Mutu Terpadu. IPB Bogor.

[16] Mulyasa, E. 2003. Menjadi Kepala Sekolah Profesional Dalam Konteks Menyukseskan MBS dan KBK. Bandung : PT. Remaja Rosda Karya.

[17] Utami, S. 2010. Kemitraan Sekolah Menengah Kejuruan dengan Dunia Usaha dan Dunia Industri melalui Praktik Kerja Industri: Studi Multisitus di SMK Negeri 3 Malang dan SMK Cor Jesu Malang. Tesis Pascasarjana Universitas Negeri Malang.

[18] Baedowi, A. (2015). Manajemen Sekolah Efektif. Jakarta : PT. Pustaka Alvabet.

[19] Muzenda, A. (2013). Lecturers' Competences and Students' Academic Performance. International Journal of Humanities and Social Science Invention, 3(1), 6. Retrieved from IJHSSI Database.

[20] Akiri, A. A. (2013). Effects of Teachers' Effectiveness on Students' Academic Performance in Public Secondary Schools; Delta State Nigeria. Journal of Educational and Social Research, 3(3), 105. Retrieved from MCSER Publishing Database.

[21] Astuty, E. (2015). Implementation Analysis of Lecturer's Pedagogical Competence on Student's Academic Achievement. Journal of Management Research, 7(2), 152. Retrieved from Macrothink Institute Database. 